\title{
(息)
}

Citation:

Dashper, K and Roth, S (2016) Sociology in the 1980s: the rise of gender (and intersectionality). Sociology. ISSN 1469-8684 DOI: https://doi.org/10.1177/0038038515620359

Link to Leeds Beckett Repository record:

https://eprints.leedsbeckett.ac.uk/id/eprint/2413/

Document Version:

Article (Accepted Version)

The aim of the Leeds Beckett Repository is to provide open access to our research, as required by funder policies and permitted by publishers and copyright law.

The Leeds Beckett repository holds a wide range of publications, each of which has been checked for copyright and the relevant embargo period has been applied by the Research Services team.

We operate on a standard take-down policy. If you are the author or publisher of an output and you would like it removed from the repository, please contact us and we will investigate on a case-by-case basis.

Each thesis in the repository has been cleared where necessary by the author for third party copyright. If you would like a thesis to be removed from the repository or believe there is an issue with copyright, please contact us on openaccess@leedsbeckett.ac.uk and we will investigate on a case-by-case basis. 


\section{Sociology in the 1980s - The Rise of Gender (and intersectionality)}

Silke Roth and Katherine Dashper

University of Southampton, UK and Leeds Beckett University, UK

Corresponding author:

Silke Roth, University of Southampton, Southampton, SO17 1BJ, UK

E-mail: silke.roth@soton.ac.uk

\section{Abstract}

The social, economic and political context of the 1980s in Britain shaped the contributions to the journal, and the early part of the decade was marked by emphasis on the interrelations between class and gender. The introduction of this e-special discusses the increasing importance of gender in sociological analysis in the 1980s. This development is related to a shift from production to consumption and a growing interest in life-style leading to the debate around "the end of class", the "cultural turn" and "identity politics". We assess the influence of articles published in the 1980s and how sociology - both the discipline and the journal - have changed since these articles have been published. The selected articles provide a historical perspective and are - as we argue - still highly relevant for the current state of the discipline and sociological debate. They illustrate the evolution of British sociology, from emphasis on class analysis in the 1970s towards the growing prominence of intersectionality and subjectivity in the 1990s and beyond. Feminist theory and research in the 1980s within and beyond Sociology indicate the importance and utility of intersectionality, even if the terminology has shifted, and the decade resulted in considerable advances in terms of the prominence, legitimacy and sophistication of gender analysis

\section{Keywords}

Gender, British sociology, class, intersectionality 


\section{Sociology in the 1980s - The Rise of Gender}

The 1980s are characterized by a shift from production to consumption and a growing interest in life-style leading to the debate around "the end of class", the "cultural turn" and "identity politics". These developments are closely related to the increasing importance of gender in sociological analysis which is the focus of this e-special. ${ }^{1}$ What can we gain from a selection of articles addressing gender that were published in Sociology about 30 years ago? What influence did these articles have? How has sociology - both the discipline and the journal - changed since these articles have been published? This is not the first time that the rise of gender in British sociology has been surveyed (Maynard 1990, Finch 1993, Delamont 2003, Platt 2007). Our e-special includes many of the articles discussed by Finch (1993), but we have only included those that were published in the 1980s as well as one more recent article to document continuity and change. We have concentrated on the debate about including women - or gender - in class analysis and the sociology of the professions, included efforts to develop new theoretical perspectives, and have chosen articles that assess the transformation of the discipline. We thus have selected articles which provide a historical perspective and are at the same time highly relevant for the current state of the discipline and sociological debate. Careful readers will note that by discussing "women", "gender" and "feminism" we are at risk of slippage (Scott 1986) - we certainly want to distance ourselves from any notion that these terms can be used interchangeably. The historical relationship between feminism and gender studies is long and complex and includes 'bringing women' in (as well as understanding men as gendered beings) as well as rethinking presumably gender-neutral concepts (labour, organizations, bureaucracy). In addition, we certainly do not want to suggest that all women are feminists or that all feminists are women.

We start out with two assessments of the discipline - Stacey's (1982) presidential address and the survey of the BSA Standing Committee on the Equality of the Sexes (1986). We then turn to the debate around women, class analysis and the sociology of professions (Hearn 1982, Goldthorpe 1983, Erikson 1984, Dale, Gilbert et al. 1985, Crompton 1987, Leiulfsrud and Woodward 1987). The transformation of sociology is reflected in the articles that were published in the second half of the 1980s which include highly influential articles theorising gender and patriarchy (Connell 1985, Walby 1989) and a feminist standpoint (Ramazanoglu 1989). This selection of papers illustrates aspects of the evolution of British sociology, from emphasis on class analysis in the 1970s towards the growing prominence of intersectionality and subjectivity in the 1990s and beyond. 


\section{Austerity, Assessments and Advances}

In her presidential address, delivered in April 1982, Meg Stacey called on the BSA to 'fight like a woman'. What was the fight about? And what does it mean to fight like a woman? Stacey addressed the cuts to the welfare State in Thatcherite Britain and associated attacks on institutions of higher education, in particular the impact on the humanities and social sciences. Some 30 years later, Britain is again in the hands of a Conservative government and its austerity politics and much of Stacey's argument remains disappointingly apt and relevant. In an earlier paper, Stacey (1981) had argued that sociological concepts related to the division of labour needed to be fundamentally rethought. In her presidential address she reviewed the impact of welfare cuts which hit women harder than men, resonating with the gendered impact of the most recent budget (Women's Budget Group 2015). In this situation, Stacey (1982) argues, women might be more likely to "put up a fight to stay human", "to be politically assertive" and "thus be more obstinate, more aggressive and carry with them a greater potential as fighters for change" due to their experience of exclusion (p. 421). She thus links the struggle for academic freedom and to preserve and improve the social sciences and institutions of learning to women's fight against oppression. A reminder of this fighting spirit not just for women - is timely.

In the following academic year (1982/83), the BSA carried out a survey on the marginality of women in the profession (BSA Standing Committee on the Equality of the Sexes, 1986) which revealed that women "tended to be overworked because of their small numbers in any one department, and because growing interest in the sociology of women and gender had resulted in increased teaching and supervision loads for them (in addition to the load of pastoral care which they carried anyway)" (p. 347). The survey also documented opposition of male sociologists to the development of women's studies. The number of women at all levels of the profession - from undergraduates to full professors and leaders of the discipline - has certainly increased significantly (Platt 2007) and feminist knowledge "added on" and "took apart" sociology and social theory (Skeggs 2008). In fact, Skeggs (2008) suggests that "the expansion of women's studies was enabled by the opening up of higher education through the neo-liberal market of Thatcherism" (p. 679). Thus, the restructuring of the public sector market, the welfare state and the education system present both a threat and an opportunity for feminists. Below we will return to the question to what these developments are reflected in Sociology.

\section{Women, Class Analysis and the Professions}

The second wave of the women's movement encompassed a range of highly influential publications, including popular books by feminists that became relevant for the transformation of sociology and 
other disciplines and the emergence of women's studies (Skeggs 2008). In fact, women's studies have from the very beginning been multi-disciplinary and sociologists of gender have always drawn on a wide range of literatures, including anthropology, history and philosophy in order to develop an understanding of the social construction of gender. How is this wider debate reflected in articles that were published in Sociology in the 1980s? Initially, gender is discussed with respect to class, a dominant theme in the early decades of the journal (see e-special on Sociology in the 1960s \& 1970s). Thus, at the beginning of the 1980s one lively debate in the journal concerned stratification and how class analysis can accommodate the increasing labour force participation of married women as well as the position of home makers.

The critique of "intellectual sexism" and calls for taking sex-based inequalities seriously in (re)conceptualising social stratification (Acker 1973) was immediately rejected (Goldthorpe 1983). Goldthorpe's defence of the "conventional view" (included in this special issue) is amongst the most frequently cited articles (rank 8) published in Sociology. Based on a combination of work- and family history data from the 1972 Oxford national social mobility survey, Goldthorpe (1983) argues that "the pattern of employment of married women is more likely to be class-conditioned than classdetermining" (p. 477). Furthermore, he considers married women's labour force participation negligible due to its intermittent nature and the high proportion of part-time working women. In addition, he rejects a "joint classification" of husbands and wives and instead proposes a measure of "socio-economic status" of families which, in addition to labour force participation, would also include education, family income and housing type (p. 483). Similarly, Erikson (1984) (also included in this e-special and in rank 5 of the most-cited articles published in Sociology) considers sex irrelevant - both for classification of work positions and of class positions of families. Although he acknowledges gender differences in patterns of career mobility, he finds no evidence for gender differences in intragenerational mobility or that women's mobility would influence the class position of families. The high frequency with which these two texts were cited is certainly due to the debate that this vigorous rejection of feminist criticism of stratification theory caused (Heath and Britten 1984, Stanworth 1984, Dale, Gilbert et al. 1985, Goldthorpe and Payne 1986, Abbott 1987, Leiulfsrud and Woodward 1987, Erikson and Goldthorpe 1988, Leiulfsrud and Woodward 1988). Of course, the debate was not restricted to Sociology, which is the focus of our review.

Among the feminist critiques, only one, Stanworth (1984) (included in this e-special), is listed among the top 50 articles of Sociology, her reply to Goldthorpe achieves rank 37. She notes that Goldthorpe not only bases his claims about class almost exclusively on men, but also fails to acknowledge how wives' dependence shapes their employment histories. Stanworth (1984) argues that "gender is implicated in the production and reproduction of the class system" and that "the subordinate class 
position of women, married or otherwise, are shaped by the dynamics of class itself" (p. 167). In the following year, Dale, Gilbert and Arber (1985) propose a framework to include women into theories of class and a methodology to measure their class location with respect to their relationship to the labour market (p. 384). They distinguish between "the 'occupational class' of the individual and the 'consumption patterns' of the family", which means that the occupational class position can be identified based on the relationship to the labour market while the unwaged labour at home which is overlooked by conventional class analysis is acknowledged through attention to consumption patterns (p. 387f). The debate about 'bringing women in' to class analysis thus paves the way for the increasing attention to consumption patterns which is characteristic of sociology in the 1990s (see especial on 'Self-Identity and its Discontents: Sociology in the 1990s").

Leiulfsrud and Woodward (1987) (included in this e-special) provide a good overview of this debate, using qualitative data and focusing on the division of labour at home. They use data from Sweden which is characterised by higher female labour force participation and more strongly gender segregated occupational structures than the UK. Their study considers the interaction between sex and class through an analysis of the division of labour of 30 cross-class families in Stockholm. Leiulfsrud and Woodward (1987) found that both class and sector mattered: men who were working in the public sector were somewhat more likely to stay at home to look after a sick child than those in the private sector. Working class-partners, regardless of sex, were more likely to stay at home. In the Swedish context, child care leave and gender equality are supported by the state and both men and women see advantages in departing from traditional gender patterns. Drawing on Bourdieu (1984), they show how working class and non-working class partners draw on different forms of cultural capital. Leiulfsrud and Woodward (1987) address the difference that the expansion of the welfare state, as well as taxation systems, job security legislation and rising costs, make for women's labour force participation. Erikson and Goldthorpe (1988) dismiss the data presented by Leiulfsrud and Woodward as "impressionistic" (p. 546), challenge its interpretation and counter it with a series of log-linear models using the Swedish National Class Study. They claim that their results do not support Leiulfsrud and Woodward's findings and speculate that this "must be seriously embarrassing to them" (p. 548). However, far from being embarrassed, Leiulfsrud and Woodward (1988) are "not impressed" by the analysis presented by their critics. Instead they point to the weaknesses of quantitative studies which only include one spouse, are limited to "easily measured attitudes and indicators" and fail to explore everyday experiences (p. 556). Furthermore, they point out that Erikson and Goldthorpe (1988) chose to only cite literature supporting their positions while ignoring alternative approaches to class analysis such as Abbott (1987). Of course, the debate on the relationship between gender and class in Sociology did not end in the 1980s even if it was 
particularly lively and prominent in this decade. Assessing the efforts to 'bring gender in', Bottero (1998) notes that "materialist accounts of gender have been dominated by the legacy of the class model" (p.483) and thus the fact that economic processes are always gendered, just as organizational processes are gendered (Acker 1990), becomes obscured.

In contrast to class analysis, the sociology of the professions appeared to be somewhat more open to feminist perspectives on employment. Hearn (1982) (included in this e-special) discusses the relationship between professionalisation and patriarchy and the distinction between (male) professions and (female) "semi-professions". Drawing on feminist literature, Hearn (1982) discusses the historical relationship of professionalisation and patriarchy (defined as a "complex set of social relations, within and by which men tend to dominate women", p. 187), in particular with respect to medical, legal and clerical professions. These professionalisation processes were intertwined with the separation of rationality and emotionality and the feminisation and control of the latter. The socialization of emotionality becomes the domain of the so-called semi-professions - nursing, health visiting, midwifery, social work and teaching - "the emerging structure by which grief, joy, loss and despair are patriarchally socialised"'” (p. 191). Hearn (1982) introduces the notion of the "patriarchal feminine" to account for roles such as matrons and headmistresses who, although still conforming to the feminine caring stereotype, reinforce masculine dominance and specialization and represent posts with considerable authority for middle and upper class women (p. 193). He shows how the semi-professions - staffed mainly by women, managed mainly by men - play a crucial role in the maintenance and development of patriarchy (p. 197). Crompton (1987) (included in this e-special) notes that both Weberian market-derived and Marxist labour exploitation theories are gender-blind and therefore proposes to locate gender "within a series of status matrices which may be constructed at different societal levels" (p. 424). She notes that statuses such as race or religious affiliation may also be approached via a matrix framework, but that class will always be a major factor. Her discussion of different forms of inequality that shape matrix locations seems to prefigure the concept of intersectionality which we discuss below.

\section{Theorising Gender and Patriarchy}

In the second half of the decade articles developing theories of gender and patriarchy are published in the journal. R.W. Connell (1985) (included in this e-special), another highly cited article (rank 41), develops a theory of gender drawing on feminism, gay liberation, psychoanalysis, sociology and psychology. Connell compares the impact of gender analysis on social theory in the 1980s to the influence of socialist class analysis in the mid-nineteenth century (p. 260) and distinguishes two approaches developing a comprehensive theory of gender. The first approach focuses on "sex roles", stereotypes and socialisation and downplays "the economic, domestic and political power men 
exercise over women" (p. 264). The second approach starts out with an analysis of power and sexual domination, but suffers from simplistic generalisations that lump together "men" and "women", overlooking the heterogeneity of both groups and conflating biological and social facts. In order to overcome the weaknesses of both approaches, Connell (1985) proposes a theory of practice drawing on Giddens and Bourdieu as well as feminist theorists such as Rubin (1975) and Rich (1980). Such an approach addresses the "practical relevance" between natural and social structures, acknowledges practices of power and sexuality and is based on the understanding that "the social process deals with the biological patterns given to it" (p. 269). These ideas are further developed in Connell's (1987) hugely influential book "Gender and Power". Similar developments were going on in other disciplines, including history. In her seminal article, Scott (1986) argues that "gender is primarily a way of signifying relationships of power" and becomes "implicated in the conception and construction of power itself" (p. 1069). In order to illustrate how these ideas have been recently theorized in Sociology, we have included Richardson (2007) in this e-special who returns to the question of the how the relationship between gender and sexuality has been theorized. She concludes her review that over the last 50 years a dramatic shift from "modernist understandings of sexuality and gender as fixed, coherent and stable have been challenged by recent trends in social theory that conceptualise these categories as plural, provisional and situated" (p. 469). Connell's (1985) paper in this e-special is an important contributor to this trend.

Walby (1989) (included in this e-special) seeks to defend the concept of patriarchy against objections that it fails to acknowledge historical and cross-cultural variations in gender relations. Defining patriarchy as "a system of social structures, and practices in which men dominate, oppress and exploit women" she calls for conceptualisations at different levels of abstraction (p. 214). She notes that in contemporary Britain patriarchy as a system of social relations "exists in articulation with capitalism, and with racism" and is composed of six structures: "the patriarchal mode of production, patriarchal relations in paid work, patriarchal relations in the state, male violence, patriarchal relations in sexuality, and patriarchal relations in the cultural institutions, such as religion, the media and education" (ibid). This means, for example, that patriarchy exists independently from capitalism in pre-capitalist as well as in socialist societies. Furthermore, ethnic differences and racism which shape the position of women in society and labour markets need to be acknowledged. By breaking down patriarchy into six structures that concern the subordination of women in the private and the public sphere, it is possible to develop a comparative and differentiated perspective on gender relations.

In her assessment of Walby's dual systems approach, Acker (1989) proposes a "shift in the theoretical object from patriarchy to gender" in order to understand "how gender is involved in 
processes and structures that previously have been conceived as having nothing to do with gender" (p. 238). Over the past thirty years the debate has not just moved from patriarchy to gender, but from gender to intersectionality. In her critical assessment, Patil (2013) notes that gender and racial hierarchies need to be understood in an historical and transnational perspective in order to overcome 'domestic intersectionality'. She illustrates this by referring to the gendered and racialized processes of colonialism and post-colonial development. Walby's (1989) paper demonstrates that although the term 'intersectionality' was rarely used 30 years ago feminist scholars were aware of the impossibility of analysing gender independently of other axes of power, division and stratification.

\section{Feminist Transformation or Compartmentalisation?}

Thirty years ago, Stacey and Thorne (1985) argued that the influence of feminism on American sociology had been hampered, first, by the dominance of functionalism and its focus on roles, socialisation and consensus, second, by the fact that gender was added as a variable in quantitative analyses and thus treated as a property of individuals, and finally, by the failure of Marxist scholars to engage with Marxist feminism. Revisiting this critique twenty years later, Ferree, Khan and Morimoto (2007) note that despite the massive increase of research on gender, the transformation of US sociology has been limited due to two processes: gender identification and gender polarization. Gender identification associates certain fields within sociology with women and men, for example sociology of gender or sociology of the family is seen as a female domain and theory and methods as male domains. Gender polarization refers to the fact that feminist research or research done by women is more likely to be considered particular ("a women's issue") while work done by and on men is considered "general". They thus argue that the discipline of sociology is and remains gendered. Has British sociology followed a different trend to its American counterpart and is there evidence of a feminist revolution in British sociology? Rather than calling for a revolution, Ramazanoglu (1989) discusses the potential of improving sociology through taking a feminist standpoint. She does this by revisiting a study on women shift-workers that she conducted in the "tradition of post-war British empiricism, within the framework of an implicitly positivist methodology" which did not adequately take account of the "significance of gender, subjectivity, emotion and power in the production of any sociological knowledge" (p. 427). This is not just a problem from a feminist perspective, but raises questions for the sociology of knowledge and philosophy of social science more broadly.

Ramazanoglu (1989) problematizes a "feminist standpoint" given the wide variation of women's experiences due to race, class, marital and parental status, age, sexuality etc., further indication that many feminists writing in the 1980s were sensitised to the importance and challenges of 
intersectionality. Considering how experiences are shaped by material conditions improves the production of scientific knowledge and she therefore concludes that "feminism can improve on male-centred sociology" (p. 440). Platt (2007) surveyed the three leading British sociological journals - the British Journal of Sociology, the Sociological Review and Sociology - between 1950 and 2004 in order to assess women's representation among authors, the topics of women's articles and the methodologies used. She finds a persistent majority of male authors, even though the proportion of female authors increased over time. Moreover, compared to female faculty members, female authors are actually slightly over-represented among authors. Platt (2007) found that "female" topics (including family, children, women, gender and feminism, p. 966) constituted $11 \%$ of the total number of articles but more than half of those published by female authors. This indicates the risk of gender identification. Platt (2007) found that a higher proportion of "theoretical" articles was published by men, and the majority of women's empirical articles were based on qualitative methods (p. 967), which suggests gender polarization. ${ }^{2}$ However, she notes that overall there have been small gender differences with respect to the use of methods and that the preference for qualitative methods is not related to "female" topics.

The 2010 International Benchmarking Review of UK Sociology notes that women and gender studies constitute a vibrant field and observes a 'weakness' with respect to quantitative methods without linking the two observations (Cohen et al. 2011). In order to study the methodological preferences of gender scholars, Cohen et al (2011) coded articles published in 2007 in 19 English-language gender, women's studies and feminist journals. Rather than a preference for qualitative methods (38\%), they found a slight majority of studies based on quantitative methods $(43 \%)$ and a smaller number of studies employing mixed methods (8\%), with $12 \%$ of articles being theoretical or using secondary sources only. However, authors with a feminist perspective were less likely to employ quantitative methods (p. 576). Both studies conclude that the preference for qualitative methods is not evidence of a feminist revolution, but characteristic of UK sociology more generally. Reflecting on editing Sociology at the beginning of the $21^{\text {st }}$ century, Crow and Pope (2008) who found themselves editing an issue of sociology and gender, conclude that "gender clearly still matters to sociologists" (p. 397) noting a "shift towards a performative view" in contrast to the political emphasis that characterised the engagement with gender in the 1980s. A few years later, Savage (2010) observed that "feminist sociology is now championed from the mainstream of the discipline" (p. 660).

What about the transformations of gender theory and gender hegemony? Our assessment of the rise of gender in the 1980s in Sociology, first in the context of the debate around gender and class analysis and second with respect to theorising gender relations, indicates an awareness of the intersection of gender, class and race/ethnicity well before the concept of intersectionality became 
popular (for a review see Cho et al. 2013). The increasing popularity of the concept has transformed gender theory and testifies to the reflexivity and commitment of feminist and gender scholars to acknowledging the multiple forms of privilege and disadvantage that shape men's and women's lives. To what extent has the concept entered and transformed sociology? A full text search of Sociology (3 August 2015) resulted in 27 items including 'intersectionality' (compared to 706 instances of gender and 1505 instances of class). The concept was found in articles addressing gender, class, race, sexuality, religion, youth, migration as well as theoretical debates around social constructivism or complexity theory. This suggests that the concept has potential to become equally relevant for class analysis or the analysis of race and ethnicity as for gender analysis. In one of the most read articles in June 2015 (rank 13), Walby, Armstrong and Strid (2012) make the case that intersectionality is of relevance for social theory more broadly (including but not limited to gender theory) and link it to concepts such as cosmopolitanism, multiculturalism, anti-racism, hybridity, identity and nationalism (p. 2).

\section{The rise of gender: The 1980s and beyond}

Our review of articles published in Sociology in the 1980s illustrates the rise of gender as a topic for empirical and theoretical consideration within the journal and the discipline more broadly. This trend has continued and gender theory and analysis remain integral to sociological research, sparking debate, controversy and theoretical advancement. The social, economic and political context of the 1980s in Britain shaped the contributions to the journal, and the early part of the decade was marked by emphasis on the interrelations between class and gender. Feminist theory and research in the 1980s within and beyond Sociology indicate the importance and utility of intersectionality, even if the terminology has shifted, and the decade resulted in considerable advances in terms of the prominence, legitimacy and sophistication of gender analysis. Although 30 years old the contributions in this e-special remain relevant and informative for contemporary sociology and illustrate that the fight for the importance of gender analysis, for the discipline, for the social sciences and for the academy (Stacey 1982) is far from won.

\section{Acknowledgements}

We thank the editors of the other e-specials, Sarah Neal and Francois Guesnet for encouraging and perceptive comments.

\section{Notes}

1. To celebrate the 50th anniversary, the editorial board decided to produce four e-special issues reflecting the contributions of the journal across the decades. Each of the four e- 
specials focuses on a different theme ('1967-1979 Sociology and Social Class' edited by Ryan and Maxwell, 'Self-Identity and Its Discontents: Sociology in the 1990s' edited by Skinner, May and Rollock; '2000-2010 Sociology and its Boundaries' ed. by Jawad, Dolan and Skillington).

2. These processes - gender identification and gender polarization - appear to be still at work as the recent Sociology Special Issue "Sociology and the Global Economic Crisis" (2014) suggests. None of the articles in the issue includes gender among the key words and overall, the references to gender, women and feminism tend to be scarce, subtle and implicit even though social reproduction and biofinancialisation are discussed. The article that most explicitly deals with racialisation and gender is the only article solely authored by women. Given the media and feminist debates around the genderedness of the financial crisis (for a critical review, see Prügl 2012, see also Walby 2013), this gender-blinkeredness (Cornwall 2003 ) is remarkable, and reflects the under-citation of female authors by male colleagues (Ferree et al. 2007). This example indicates that there is a continuing need for Sociology as a journal - as well as the discipline more widely - for gender reflexive practice.

\section{References}

Abbott P (1987) Women's Social Class Identification: Does Husband's Occupation Make a Difference? Sociology 21(1): 91-103.

Acker J (1973) Women and Social Stratification: A Case of Intellectual Sexism. American Journal of Sociology 78(4): 936-945.

Acker J (1989) The Problem with Patriarchy. Sociology 23(2): 235-240.

Acker J (1990) Hierarchies, Jobs, Bodies: A Theory of Gendered Organizations. Gender and Society 4(2): 139-158.

Bottero W (1998) Clinging to the Wreckage? Gender and the Legacy of Class. Sociology 32(3): 469490. 
Bourdieu P (1984) Distinction. A Social Critique of the Judgement of Taste. London, Routledge and Kegan Paul.

BSA Equality of the Sexes Committee (1986) Teaching Gender - Struggle and Change in Sociology BSA Standing Committee on the Equality of the Sexes. Sociology 20(3): 347-361.

Cho S, Crenshaw KW andMcCall L (2013) Toward a Field of Intersectionality Studies: Theory, Applications, and Praxis. Signs 38(4): 785-810.

Cohen, RL, Hughes C and Lampard R (2011) The Methodological Impact of Feminism: A Troubling Issue for Sociology? Sociology 45(4): 570-586.

Connell RW (1985) Theorising Gender Sociology 19(2): 260-272.

Connell RW (1987) Gender and Power. Stanford, Stanford University Press.

Cornwall A (2003) Whose Voices? Whose Choices? Reflections on Gender and Participatory Development. World Development 31(8): 1325-1342.

Crompton R (1987) Gender, Status and Professionalism. Sociology 21(3): 413-428.

Crow G and Pope C (2008) Editorial Foreword: Sociology and Gender. Sociology 42(3): 397-399.

Dale A, Gilbert GN and Arber S (1985) Integrating Women into Class Theory. Sociology 19(3): 384408.

Delamont S (2003) Feminist Sociology. Thousand Oaks, Sage.

Erikson R (1984) Social Class of Men, Women and Families. Sociology 18(4): 500-514.

Erikson R and Goldthorpe JH (1988). 'Women at Class Crossroads': A Critical Note. Sociology 22(4): 545-553. 
Ferree MM, Khan S and Morimoto SA (2007) Assessing the feminist revolution: The presence and absence of gender in theory and practice. In: Calhoun C (ed) History of Sociology in America: ASA Centennial Volume. Chicago, University of Chicago Press: 438-479.

Finch J (1993) Conceptualising gender. In: Morgan, DHJ and Stanley, L (eds) Debates in Sociology. Manchester: Manchester University Press.

Goldthorpe JH (1983) Women and Class Analysis: In Defence of the Conventional View. Sociology 17(4): 465-488.

Goldthorpe JH and Payne C (1986) On the Class Mobility of Women: Results from Different Approaches to the Analysis of Recent British Data. Sociology 20(4): 531-555.

Hearn J (1982) Notes on Patriarchy, Professionalization and the Semi-Professions. Sociology 16(2): 184-202.

Heath A and Britten N (1984) Women's Jobs do Make a Difference: A Reply to Goldthorpe. Sociology 18(4): 475-490.

Leiulfsrud H and Woodward A (1987) Women at Class Crossroads: Repudiating Conventional Theories of Family Class. Sociology 21(3): 393-412.

Leiulfsrud H and Woodward AE (1988) Women at Class Crossroads: A Critical Reply to Erikson and Goldthorpe's Note. Sociology 22(4): 555-562.

Maynard M (1990) The Re-Shaping of Sociology? Trends in the Study of Gender. Sociology 24(2): 269-290.

Patil V (2013) From Patriarchy to Intersectionality: A Transnational Feminist Assessment of How Far We've Really Come. Signs 38(4): 847-867.

Platt J (2007) The Women's Movement and British Journal Articles, 1950-2004. Sociology 41(5): 961-975. 
Prügl E (2012) "If Lehman Brothers Had Been Lehman Sisters...": Gender and Myth in the Aftermath of the Financial Crisis. International Political Sociology 6(1): 21-35.

Ramazanoglu C (1989) Improving on Sociology: The Problems of Taking a Feminist Standpoint. Sociology 23(3): 427-442.

Rich A (1980) Compulsory Heterosexuality and Lesbian Existence. Signs 5(4): 631-660.

Richardson D (2007) Patterned Fluidities: (Re)Imagining the Relationship between Gender and Sexuality. Sociology 41(3): 457-474.

Rubin G (1975) The Traffic in Women: Notes on the" Political Economy" of Sex. In Reiter, R (ed) Toward an Anthropology of Women. 157-210.

Savage M (2010) Unpicking sociology's misfortunes*. The British Journal of Sociology 61(4): 659-665.

Scott JW (1986) Gender: A Useful Category of Historical Analysis. The American Historical Review 91(5): 1053-1075.

Skeggs B (2008) The dirty history of feminism and sociology: or the war of conceptual attrition. The Sociological Review 56(4): 670-690.

Stacey J and Thorne B (1985) The Missing Feminist Revolution in Sociology. Social Problems 32(4): 301-316.

Stacey M (1981) The division of labour revisited or overcoming the two Adams. In: Abrams P (ed) Practice and progress: British sociology 1950-1980. London, Allen \& Unwin, 172-190.

Stacey M (1982) Social Sciences and the State: Fighting Like a Woman. Sociology 16(3): 406-421.

Stanworth M (1984) Women and Class Analysis: A Reply to John Goldthorpe. Sociology 18(2): 159170.

Walby S (1989) Theorising Patriarchy. Sociology 23(2): 213-234. 
Walby S (2013) Finance versus democracy? Theorizing finance in society. Work, Employment \& Society 27(3): 489-507.

Walby S, Armstrong J and Strid S (2012) Intersectionality: Multiple Inequalities in Social Theory Sociology 46(2): 224-240.

Women's Budget Group (2015) The impact of women of July budget 2015. A budget that undermines women's security. from http://wbg.org.uk/wp-content/uploads/2015/04/July-budgetbriefing-2015-WBG.pdf. Last accessed 4 November 2015

Silke Roth is Associate Professor of Sociology in the Department of Sociology, Social Policy and Criminology at the University of Southampton (UK). Her areas of research include the participation in and the impact of voluntary organisations, social movements and non-governmental organizations. Her publications include The Paradoxes of Aid Work. Passionate Professionals (Routledge 2015), Gender Politics in the Expanding European Union (Berghahn 2008) and Building Movement Bridges. The Coalition of Labor Union Women (Greenwood 2003), journal articles in Social Politics, Gender \& Society, Third World Quarterly, Sociological Research Online and the Journal for Risk Research as well as numerous book chapters and edited volumes. She is an editorial board member of Sociology.

Katherine Dashper is senior lecturer in the Institute for Sport, Physical Activity and Leisure at Leeds Beckett University. Her research interests focus predominantly on issues of identity in sport and leisure contexts, particularly in relation to gender and embodiment. Her current research explores human-animal relations within equestrian sport and leisure, and the gendered aspects of involvement in a mixed-sex, but often female-dominated, sporting environment with strong masculine origins. Katherine is editor of three books (Rural Tourism: An International Perspective, 2015, Cambridge Scholars; Sports Events, Society and Culture, 2014, Routledge; Diversity, Equity and Inclusion in Sport and Leisure, 2014, Routledge) and on the associate editorial board of Sociology.

Date submitted: September 2015

Date accepted: November 2015 